\title{
City branding of Palembang: understanding cultural identification through logo and tagline
}

\author{
Rahma Santhi Zinaida ${ }^{a, 1, *}$, Sunarto ${ }^{\text {b,2 }}$, Manik Sunuantari ${ }^{b, 3}$ \\ a Student of Post Graduate Sahid University Jakarta, Jalan Jendral Sudirman No 86, Jakarta 10220, Indonesia \\ b Lecture of Post Graduate Sahid University Jakarta, Jalan Jendral Sudirman No 86, Jakarta 10220, Indonesia \\ ${ }^{1}$ rahmasanthi@binadarma.ac.id*; ${ }^{2}$ Martosuwitosunarto@gmail.com; ${ }^{3}$ manik_sunuantari@yahoo.com \\ * corresponding author
}

ARTICLE INFO

Article history

Received 2020-04-21

Revised 2020-05-23

Accepted 2020-06-03

\section{Keywords}

Cultural

Identification

City

Branding

Logo

\section{ABSTRACT}

City branding is believed to be a way to promote the city. Some of the cities in the world have strong branding because they are made following the identity of the city. The research problems in this research are what visual elements were included in the Palembang city logo; this paper aims to identify the cultural aspect of each component contained in the Palembang city logo by using the theory of logo. This research was using a case study analysis and descriptive qualitative research. Based on the review of the logo and tagline from the Palembang city logo, in conclusion, Palembang city branding has already completed the elements of a good logo such as Persuasive, Harmonious, Supporting a local culture, Must be supporting local Culture. The real situation of the city was designed in original \& Distinctive. There are several cultural influences represented by the logo. Chinese and Japanese cultural influences have an essential role in the logo of the city branding Palembang.

This is an open access article under the CC-BY-SA license.

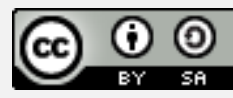

\section{Introduction}

The city is pride and hope. It means that pride in the past and the promise to achieving the future. As a part of a province and a country, cities have more specific advantages, uniqueness, and characteristics. So, the specificity can be shown easily, and finally remembered by anyone who visits it. The face of the city is always changing, and its shape ultimately reflects the cultural, social, political, and economic characteristics of the people. The formation of the has an embodiment with the elements of the city's components, such as the shape of buildings, road patterns, patterns of land use, open space, and skylines in addition to being influenced by the natural environment and community behavior, is also manifested in a decision making the process of the city authorities during his reign.

Most of the cities in the world have strong branding because they have a following the identity of the city. In Europe, cities like London and Paris are unique in terms of maintaining local architecture, and London has succeeded in becoming the world's best city branding in 2017. Each region in the form of regencies or cities each has a unique culture and character of the community different as a reflection of social, Culture, and natural environment. Based on the social and cultural aspects, every city must have an identity that becomes a symbol of the area represented by a logo. 
The city logo is a visualization of values embraced by the district. That is why a logo besides considering aesthetic values it is also laden with symbolic meanings that are expected to be a source of inspiration and motivation from the area in managing and developing the region. Other than that, the embodiment of a logo sometimes too lifts just for an event. There is a historical value that must represent by the city logo. But, It is the claim of Hospers [1] that the logo is not enough to build city identities because it may only apply for corporates, products, and services.

Almost every city in the world has a city branding. On the American continent, New York is still the best one. According to the Resonance Consultant, New York gets the third rank in the world as a city that has the best city branding in the world. From the Asian continent, Singapore stays in second ranks for the best city branding in the world by Resonance, [2] shows data that In Indonesia, Bali became a province with branding that was considered successful in the international eye, one of them through. People know Indonesia through the popularity of Bali or known as "The Island of Gods." Bali, as 'the island of God', successfully maintains an authentic and reflects a blend of Culture, religion, and history that shape the identity of a city.

In 2018, Ubud in the 'Gianyar' became a district on Bali that was included in the top 15 most beautiful cities in the world, version of "Travel \& Leisure." Ubud got 9th ranks for the best city in the world and 4th rank of the best city in Asia. The first rank for two years in a row is occupied by the city of San Miguel de Allende, Mexico. In 2019, Ubud in Indonesia re-entered the 6th position of the 15 best cities in the world version of Travel + Leisure.

Besides Bali, one of the cities in Indonesia that using a city branding is Palembang. Palembang even imitates Bali in the tourism sector. As the oldest city in Indonesia, Palembang continues to improve its city branding at the national and international level, because, in 2018, Palembang hosted the biggest sporting event, ASIAN GAMES. One of the elements of city branding created by the government was making a city logo. But on its way, the government often changes the logo and focus of the branding; this also becomes a problem for Palembang city branding. In addition to the logo and slogan, the focus of regional development continues to change. Branding itself is carried out by a place to attract tourists, and another reason is to form a positive image and gain immediate honor or prestige for local products that are exported [3].

Like brands, cities satisfy functional, symbolic, and emotional needs, and the attributes that meet those needs need to focus on the city's unique proposition [4]. Branding provides a good starting point for city marketing [5] There is a growing body of practice and research around place branding. Recurrent themes within the various disciplines that discuss place branding include [6]: comparisons between branding a product/service and destinations/cities ([7]; [8]; [9]).

In constructing this research, the researcher traced previous studies that had a similar theme to the investigation. Because city branding is a combination of many scientific disciplines such as economics, social, architecture, psychology, Culture, and so on, previous research that is a reference for researchers also has a diversity of scientific disciplines and studies. El Saka's research [10] examined how sustainability in managing city branding can be a useful tool for stably attracting tourists.

Another research that came from Yumrukaya \& Diren on Kreutz [11] about analysis compares how a Turkish city was seen from the perspective of Europe and local East Asia. They analyze that Turkey builds from the same history and cultural heritage. Turkey uses strong city branding elements. The analysis also shows that Turkish cities view and represent themselves as "tourist destinations," think of themselves as city brands and invest in branding.

\section{Theoretical Framework}

\subsection{City Branding}

Place branding has thus become an urban governance strategy for projecting images and managing perceptions about places ([12];[13];[14];[15]) Merrilees et al. observed that "many cities now understand the value of their brand and to some extent, how it could be designed and managed [16]. City branding is believed to be a way to promote the city. On a local scale, city imagery differs in location. Although all six cities have their strategies, some cities fail to carry images or promotional messages. Symbols, colors, types, all actions for that purpose, and reflect the cultural 
heritage, history, and location of the city and have a Western way of communication with the world. From the previous research, we can conclude that city branding has a form of representing an identity of a city and play an essential role in promoting the city

Brand identity is a component associated with the creation of the essence of the brand. The critical elements in brand identity are the functional and experiential attributes of the brand. Brand identity is the active part of the image-building process [17] involving the creation and maintenance of a unique set of associations projected through brand elements [18]. Image is the sum of beliefs, ideas, and impressions that people have of the place [19] Brand identity development takes place through the analysis of the strengths and weaknesses embedded in the tangible and intangible attributes of the area [20].

\subsection{Logo and Tagline}

Carter [21] defined that a logo is the identity of a company in a visual form that can be applying in various facilities and company activities as a form of visual communication. A logo can also be called a symbol, image mark, trademark, which serves as a symbol of the identity of a business entity and identification that is characteristic of the company ". A logo is inseparable from the essential fine arts elements that shape it. Adams on Ramanda [7] explained that the visual aspects forming a logo consist of lines, shapes, colors, and typography.

The template is used to format your paper and style the text. All margins, column widths, line spaces, and text fonts are prescribed; please do not alter them. You may note peculiarities. For example, the head margin in this template measures proportionately more than is customary. This measurement and others are deliberate, using specifications that anticipate your paper as one part of the entire proceedings, and not as an independent document. Please do not revise any of the current designations.

Nowadays, the role of visual symbols as a form of communication is crucial, given that its existence is very unlimited in our daily lives. According to Evelyn Lip [7] the logo or trademark must follow the conditions below:

1. Must be supporting local Culture.

2. The logo must carry out the situation of the city.

3. Actually or activities of the company and describe the commercial goals of the organization it represents, while trademarks must designing to represent the products of a company. It must be a visual communication tool.

4. Must combine the right writing/letters so that it can convey the intended message logically and clearly.

5. The design must be harmonious.

6. It must be balanced and, therefore, can be black and white or balanced in color.

7. The logo must depict a rhythm and proportion.

8. It must be artistic, elegant, simple but has an emphasis or focal point.

Meanwhile, according to Carter [21], a good logo must include the following:

1. Legible, or has a reasonably high level of readability though

2. applied in various sizes and different media.

3. Original \& Distinctive, or have distinct distinctiveness, uniqueness, and distinguishing values

4. Simple, easily capture, and understood in a relatively short time.

5. Memorable, or quite easy to remember, because of its uniqueness, even over a long period.

6. Easily adapted for all visual media. Here, the ease of applying a good logo that involves physical form, color, and logo configuration on various graphic press need to be taken into account in the declaration process to avoid difficulties in its application 
7. Easily associated with the company, a good logo will be easily connected or related to the type of business and image of a company or organization

Images and identity claims captured in slogans and logos and make the role of planned symbolic brand elements complicated, and this complexity is what this study examines [22]. The logo in planning corporate identity design is like a body that can communicate the contents of the primary image of the product or company concerned. Logo, as one of the applications of corporate identity, can also function as a differentiator between one company and another. A logo is inseparable from the essential fine arts elements that shape it. Adams explained that the visual aspects forming a logo consist of lines, shapes, colors, and typography. Eric Swartz,[23] a writer and brand tagline expert, defines the tagline as concise word order (usually no more than seven words), placed alongside a logo, and containing a strong brand message aimed at a specific audience. Logo and tagline usually interconnecting meaning and represent many symbols to the company. The six dimensions used to measure a brand tagline, according to Eric Swartz, are as follows: Original, Believable, Simple, Provocative (can influence or stimulate), Persuasive or convincing, and Memorable (easy to remember).

The six dimensions used to measure the tagline of a brand, according to Swartz on Rustan [23], are as follows:

1. Original, that is, a slogan must be authentic or original, and the expressions conveyed are unique or special or are ordinary words in everyday life.

2. Believable is what a brand in the tagline promises according to what consumers will feel or get.

3. Simple is the expression or meaning of a tagline that can be understood by consumers.

4. Provocative (can influence or stimulate) if consumers can be inspired and moved when reading or knowing a slogan.

5. Persuasive (convincing) that is selling an idea so that it can make consumers move and make them think about a brand.

6. Memorable (easy to remember) that makes an impression or influence lasting or long.

Despite the growing interest in the field, the application of place branding is not without criticism (e.g., [24]; [25]; [26]) The critiques range from the democratic legitimacy of place branding [12] to whether or not brand management strategies fit areas [27] Several authors also point to difficulties inherent to place brandings, such as the great variety of target groups, the complexity of different messages, multiple spatial scales, competing interests, and the diverse institutional context (e.g., [2]; [28]; [29]; [30]). These criticisms and difficulties aside, there are no fundamental barriers to place branding, but further academic underpinning is needed [31].

\subsection{Cultural Identification}

Cultural differences may be the primary obstacle to developing internationally accepted brands for a city, especially those who live in developing countries with more traditional societies. The reason for this problem was a conflict stemming from a lack of knowledge about cultural differences. In terms of solving this problem is to understand the values of different cultures, it is essential to analyze the inherent similarities and differences in cultures [32] The best way is to find the different communication styles in cross-cultural communication situations by investigating he variations in cultural dimensions. The four cultural aspects of Hofstede [33]; [34]; [35] hidden dimension are the representative theories for understanding and explaining cultural differences

The Culture that belongs to a group of people forms a characteristic and differentiates it from other groups. Thus, Culture is the identity of the fellowship of human life. Without them realizing that local Culture is a significant factor in the formation of national Culture and the Culture of the region that they have is a nation's wealth that is very high in value and needs to be preserved by each individual in the community. In general, they do not realize that Culture is a national identity that reflects all aspects of life in its environment. Nuraeni and Alfan [36] defines a simple understanding of Culture as follows: 
1. Culture, in the broadest sense, is the whole system of ideas, actions, and results of social work in the life of society obtained through learning. The term culture is used to indicate the physical consequences of social work, although it is inseparable from the influence of human thought patterns (ideas) and behavior (actions). Culture as a system provides an understanding that created from the results of deep reflection and the repeated studies of a problem faced by humans so that something is considered pure and right.

2. Culture, in the narrow sense, can be the term culture or often called Culture, which contains an understanding of the whole system of ideas and actions. Understanding culture or Culture was intended to mention the values used by a group of people in thinking and acting. Culture as a system is also the result of repeated studies of a problem at hand.

Culture is a view of life from a group of people in the form of behavior, beliefs, values, and symbols that they receive unconsciously, all of which are passed on through the process of communication from one generation to the next [37]. Based on the description before, it is explaining about the importance of documenting the meaning of values contained in each region's and city branding, especially in Palembang. The uniqueness of this research is, in a city logo, where the characteristics of the logo must be simple, so it easy to remember. The logo must contain a variety of cultural values. It will shape the character and the excellence of a city. of course, if a city has a high cultural and historical importance, it will require details that must be considered so that no cultural characteristics are left behind. Then the research problem is what visual elements were included in the symbol Palembang city logo and what is the multicultural aspects of each component contained in the Palembang city logo.

\section{Method}

Poespowardojo \& Alexander define that the method is a way individuals take a sure way to prove a theory [38]. In this research, the technique used is the Case Study. Yin stated that case studies could also be used in the field of economic studies for cities or regions. Sequential means is an example of something happening, the actual conditions of a situation or situation, and the environment or certain conditions about people or something in a city can be examined.

This research was using a case study analysis and descriptive qualitative research. By using a qualitative method, will describe the elements visual, source of inspiration, meaning, and cultural influence from the city logo. The data collected are from library research and interviews. Primary data is data obtained or collected directly in the field by the researcher. Primary data can be obtained from the key informant and additional informant.

Secondary data is used to support primary data and information that has been obtained from library materials, literature, previous research, journal, books, and many others. Data reduction is a process of selecting, focusing attention on the simplification, abstracting, and transformation of the initial data that arise from written records in the field. This data reduction takes place continuously during qualitative research. During the data reduction process, the next steps are:

1. Categorizing data (Coding) is an effort to sort each data unit into parts that have something in common

2. Data interpretation is the search for a broader understanding of data that has been analyzed, or in other words, analysis is a detailed explanation of the true meaning of research data

Triangulation is a principle for data checking model to determine whether a data is really appropriate to describe the phenomenon in a study. Therefore many ways can be done based on the data held in the research itself. In this research, triangulation can be done by source triangulation, personal triangulation (informants), theory triangulation, method triangulation. In this research, we are using source triangulation. 


\section{Results and Discussion}

A literature survey reveals that there are mainly three approaches for promoting cities: cultural mega-events, restoration, and promoting heritage and the construction of iconic buildings ([39]; [40]). The first Palembang city logo was launched on Saturday, 17 June 2017, right on the birthdate of Palembang, 1334 years old. However, this logo has received criticism from the Indonesian Ministry of Tourism because it is considered too long and hard to remember. So, the Ministry of Tourism is willing to help to revise the Palembang city branding logo by bringing a logo consultant. Then, in April 2018, the city branding of Palembang "Charming Palembang" was launched, Here is the following logo "Charming Palembang":

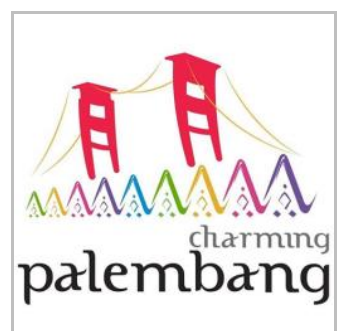

Fig. 1.Palembang city branding logo

Then, in April 2018, the city branding of Palembang "Charming Palembang" with the Ampera bridge logo design with the hologram of the Musi River in the form of nine river branches called "Batang Hari Sembilan," was completed. The Ministry of Tourism and government partners as city branding consultants suggest uniting the South Sumatera branding and the city of Palembang into one logo because the South Sumatra branding is very close to the city of Palembang.

From 4 elements of the logos (Line, shape, color, \& typography) that we break down into two figures and one tagline, see figure 2. The First figure is The Ampera bridge, and the second figure is a triangle shape. The slogan is Charming Palembang. Beside break down by the four elements, this analysis also based on what Carter [21] defines a good logo should be liked. The Ampera bridge shape shows a more flexible, oblique position. It looks like a curved, indicates that the bridge symbol was entirely humanist, informal, looks like the original shape of the bridge, and more readily accepted by the public awareness.

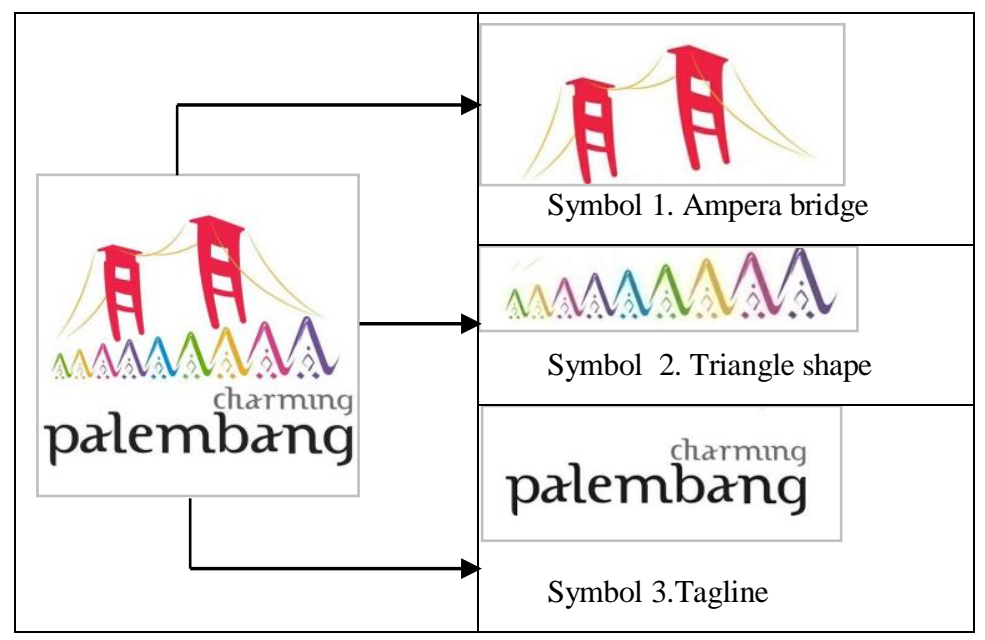

Fig. 2. Palembang city branding logo

Ampera bridge was an iconic creature. As a highlighted history, at that time, Indonesia has received war relief funds from the Japanese government, and Soekarno (1st president of Indonesia) planned that war reparations funds would be the capital in the construction of the Musi bridge in 1958. This Ampera bridge contains The Japanese style of architecture brought by its architects from Japan. This bridge was also funded by Japan and influenced by Japanese Culture. The red 
color (see figure 3) in this bridge image is influenced by Chinese Culture, where the majority of Palembang residents are Chinese descendants that believe red as a lucky color and a symbol of the element of fire / Huo, which symbolizes joy, hope, luck, and happiness. Psychologically, the color Psychologically, the color red symbolizes courage, love, and a strong desire and determination. Red is easy to attract attention.

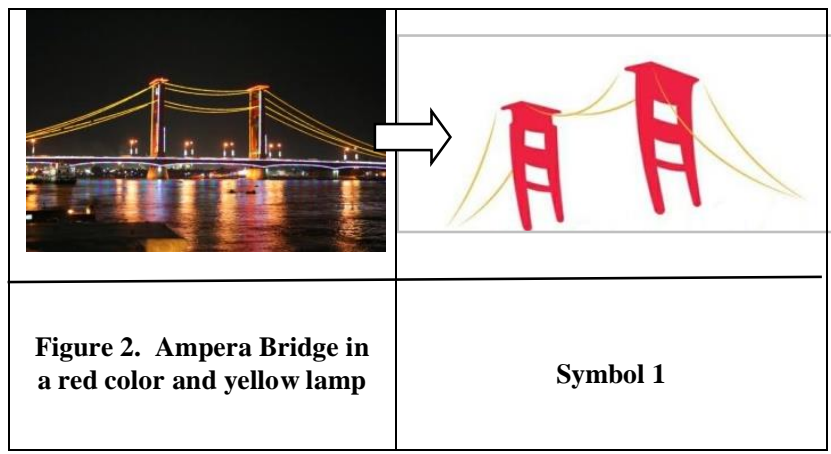

Fig. 3. Ampera bridge symbol

Palembang people believe that the Ampera Bridge is an ideological construction of the city of Palembang. Since then, the Ampera Bridge is a form of community ideals by uniting two districts separated by the Musi River, Seberang Ulu, and Seberang Ilir. Visually, Figure 3 shows an image of the Ampera bridge with a black line and a visual representation of a light cable among the bridge. When viewed in shape form, symbol 1 depicts the Ampera bridge from the side view; it looks like the roof of a limas rooftop in figure 4, which is a traditional house of Palembang. 'Rumah Limas.' Rumah Limas is also the pride of the Palembang community

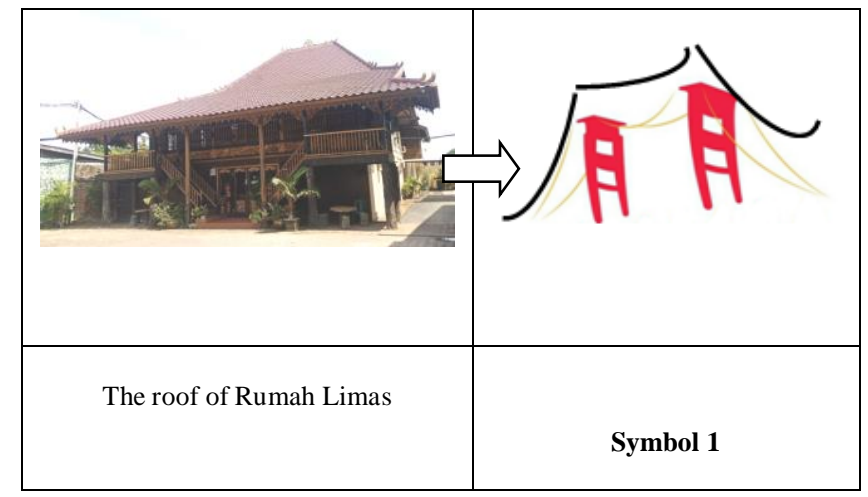

Fig. 4. Traditional house of Palembang 'Rumah Limas'

Based on symbol two or figure 5, there are nine triangles. That triangles also look like a zig-zag patterns (Diagonal or curve) line that looks like the ripples of the Musi River, with nine triangles that represent the "Batang Hari Sembilan" as a symbol for nine rivers, including Musi as the biggest river in South Sumatera. Inside the triangle, there is an element look like a strike the hill in a row. The zig-zag triangles represent the geographical location of Palembang that is surrounded by a line of hills, which is during the kingdom of Crivijaya became a means of defense attack from the enemy.

This triangle in symbol two or figure 5 shows many cultural elements, the symbol of "Pucuk Rebung," its a kind of motif on the 'songket,' which is a characteristic of Palembang woven fabric. "Pucuk" means the top of and "rebung" were similar to a kind of bamboo. The symbolize of "Pucuk Rebung" represent good hope because bamboo is a tree that does not fall easily by strong winds; the Chinese Culture inspires it. The shoots of bamboo are always present in every 'songket' as the head 
of the fabric called 'tumpal' In figure 5, there are many elements of the line but still do not eliminate the symbol so that it can be identified as the meaning and aspects of cultural influence in it.

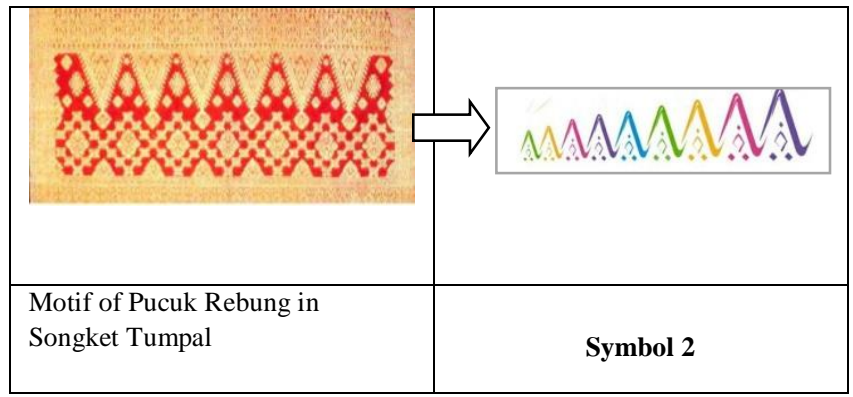

Fig. 5. 'Pucuk rebung' motif in 'songket'

Long before the Chinese people have already included "Pucuk Rebung" as motifs in 'songket'. That patterns had already been found in Pasemah megalith statues in Lahat, Pagar Alam, South Sumatera. The symbol that lookalike a zig-zag was believed as a river and represented the hill of 'bukit barisan'. So that, the existence of a culture that is sustainable through design and a motif certainly creates a diversity of history and Culture illustrated in a 'songket' motif, which eventually also becomes one of the elements in the logo of Palembang city branding which were Original \& Distinctive. The typography of the tagline was quite simple; the symbol clearly explains about the bridge and river. Moreover, it is easily captured and understood in a relatively short time. From the color perspective, The "Charming Palembang" tagline is brighter than the logo before and also connect with the color of "Wonderful Indonesia." The name Palembang itself was derived from gold panning activities carried out by the people of the Kuto Gawang kingdom, opposite the Kemaro Island. Based on history, Palembang contains two words, 'Pa' and 'Limbang.' Local people usually called Palembang. 'Limbang' is taken from a Javanese word meaning to clean up the seeds or metals.

Local people were filtering and cleaning up the seeds by using a small basket; the dirty seeds are shaken in the river; it is a kind of people's activity. Whereas, 'Pa' is a preposition used by Javanese and Malayu people if they want to mention where a business or situation takes place. 'Palimbang' is often called Palembang by the local people and its surroundings because the mention was based on the mother languages. The overall tagline was Legible or has a reasonably high level of readability though. Each logo must have a dominant color. Psychologically, the dominant color has a strong emotional expression related to the company's image and, for this case can represent the image of the city. Every city is aware that the color of the logo can be used to build public perception. The colors blend and give a highlight to each component, but do not cover up the other parts. These colors in Palembang city branding have a similarity with Indonesian branding "Wonderful Indonesia." Red was the dominant color that represents Chinese Culture. Other colors such as yellow, purple, blue, and green represent nation branding "Wonderfull Indonesia." For the tagline, "Charming Palembang" has much meaning. More simply, there is only the word 'charming' and the city names 'Palembang.' It is easier to remember because it consists of 2 words.

Furthermore, in terms of visuals, people will find it easier to remember images with colors in them. The word charming illustrates the advantages of the city of Palembang as an attraction for tourists. Charming can also be used to describe the feeling of pleasure that is very happy. The word "Charming Palembang" describes several advantages such as the oldest city and waterfront city, history, Culture, culinary, to modern infrastructure. The color of the words 'charming' on the logo is gray, and the black color on the words 'Palembang.' Black is the absence of color. Black color can absorb the colors that are nearby. This color has the property of absorbing other colors. So, most people use black as a color balancer on the logo design. From the explanation above, all aspects of a good logo will reveal the uniqueness and characteristics of a city. By looking deeply into the meaning and message to be conveyed on each element in this logo, it will show what cultural values contained therein. 
Table 1. The aspect of a good logo / city branding

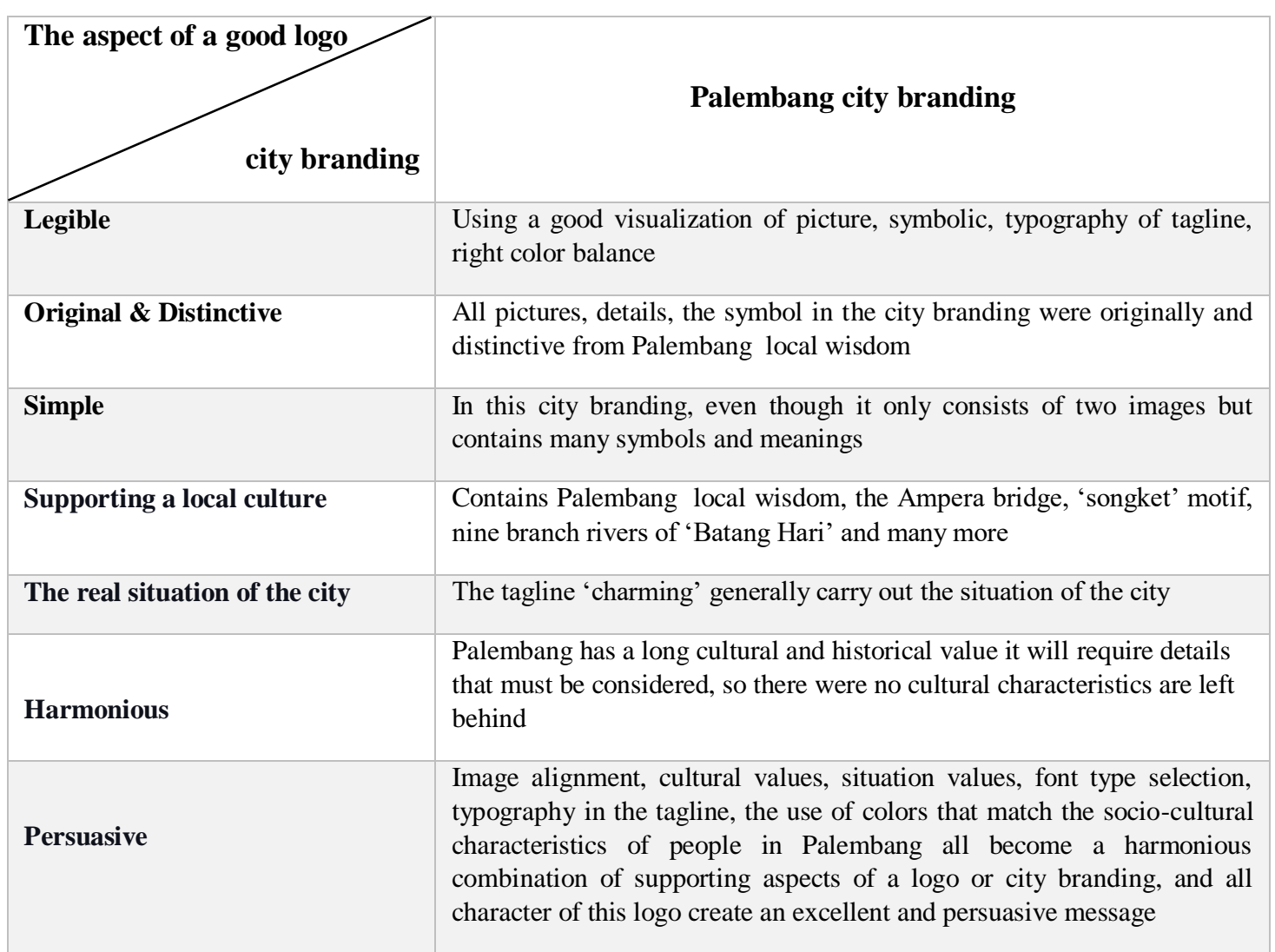

\section{Conclusion}

Palembang city branding has already completed the elements of a good logo such as Persuasive, Harmonious, Supporting a local culture, Must be supporting a local culture. The real situation of the city was designed in original \& Distinctive. Based on the analysis of the logo and tagline from the Palembang city logo, there are several cultural influences represented by the logo. Chinese and Japanese cultural influences have an essential role in the logo of the city branding Palembang. The meaning and significance of the cultural influence are seen in the central element in the logo, namely in the Ampera bridge image. When returning to the history of the Ampera bridge image, which is made by the Japanese then combined with the red color, the symbol of the Amepra bridge on the city branding logo of Palembang indeed contains multicultural meanings.

\section{Acknowledgment}

By this acknowledgment, i would like to thank the minister of the tourism department of Palembang as a key informant and Mark plus.Inc as the branding consultant who was making this city branding of Palembang also as an additional informant. 


\section{References}

[1] J. Eshuis and A. Edwards, "Branding the City: The Democratic Legitimacy of a New Mode of Governance," Urban Stud., vol. 50, no. 5, pp. 1066-1082, 2013, doi: 10.1177/0042098012459581.

[2] E. Braun, J. Eshuis, and E. H. Klijn, "The effectiveness of place brand communication," Cities, vol. 41, no. PA, pp. 64-70, 2014, doi: 10.1016/j.cities.2014.05.007.

[3] D. Peel and G. Lloyd, "New communicative challenges: Dundee, place branding and the reconstruction of a city image," Town Plan. Rev., vol. 79, no. 5, pp. 507-532, 2008.

[4] L. Zhang and S. X. Zhao, "City branding and the Olympic effect: A case study of Beijing," Cities, vol. 26, no. 5, pp. 245-254, 2009.

[5] B. Merrilees, D. Miller, and C. Herington, "Multiple stakeholders and multiple city brand meanings," Eur. J. Mark., vol. 46, no. 7, pp. 1032-1047, 2012, doi: 10.1108/03090561211230188.

[6] G.-J. Hospers, "City branding and the tourist gaze," in City Branding, Springer, 2011, pp. 27-35.

[7] Resonance, "WORLD’S BEST CITIES A Ranking of Global Place Equity,” 2018.

[8] M. Roll, "Asian brand strategy," in Asian Brand Strategy (Revised and Updated), Springer, 2015, pp. $107-140$.

[9] S. K. Rainisto, Success factors of place marketing: A study of place marketing practices in Northern Europe and the United States. Helsinki University of Technology, 2003.

[10] K. L. Keller, M. G. Parameswaran, and I. Jacob, Strategic brand management: Building, measuring, and managing brand equity. Pearson Education India, 2011.

[11] V. Harmaakorpi, K. Kari, and S. Parjanen, "City design management as a local competitiveness factor," Place Brand. Public Dipl., vol. 4, no. 2, pp. 169-181, 2008, doi: 10.1057/pb.2008.7.

[12] H. Gaggiotti, P. L. K. Cheng, and O. Yunak, "City brand management (CBM): The case of Kazakhstan," Place Brand. Public Dipl., vol. 4, no. 2, pp. 115-123, 2008.

[13] G. J. Ashworth and H. Voogd, "Marketing of tourism places: What are we doing?," J. Int. Consum. Mark., vol. 6, no. 3-4, pp. 5-19, 1994.

[14] P. Kotler, C. Asplund, I. Rein, and D. Haider, Marketing places Europe: How to attract investments, industries, residents and visitors to cities, communities, regions, and nations in Europe. Financial Times, 1999.

[15] S. Hanna and J. Rowley, "Towards a strategic place brand-management model," J. Mark. Manag., vol. 27, no. 5-6, pp. 458-476, 2011, doi: 10.1080/02672571003683797.

[16] L. A. Cai, "Cooperative branding for rural destinations," Ann. Tour. Res., vol. 29, no. 3, pp. 720-742, 2002, doi: 10.1016/S0160-7383(01)00080-9.

[17] J. Gnoth, "Leveraging export brands through a tourism destination brand," J. Brand Manag., vol. 9, no. 4, pp. 262-280, 2002.

[18] M. Kavaratzis and G. J. Ashworth, "City branding: an effective assertion of identity or a transitory marketing trick?,” Tijdschr. voor Econ. en Soc. Geogr., vol. 96, no. 5, pp. 506-514, 2005.

[19] S. El Sakka, "Sustainability as an Effective Tool for a Place Branding: An Application on El Gouna City, Egypt," Int. J. Environ. Sci. Dev., vol. 7, no. 11, pp. 861-866, 2016, doi: 10.18178/ijesd.2016.7.11.895.

[20] E. de A. Kreutz, "Anais do II Congresso Internacional de Marcas/Branding: conexões e experiências." Editora UNIVATES, 2016.

[21] D. E. Carter, Logos redesigned: How 200 companies successfully changed their image. Harper Collins, 2005.

[22] S. Kladou, M. Kavaratzis, I. Rigopoulou, and E. Salonika, "The role of brand elements in destination branding," J. Destin. Mark. Manag., vol. 6, no. 4, pp. 426-435, 2017, doi: 10.1016/j.jdmm.2016.06.011.

[23] R. Surianto, “Mendesain Logo,” Jakarta PT Gramedia Pustaka Utama, 2009. 
[24] G. Evans, "Hard-branding the cultural city-from Prado to Prada," Int. J. Urban Reg. Res., vol. 27, no. 2, pp. 417-440, 2003.

[25] J. Jansson and D. Power, The image of the city: Urban branding as constructed capabilities in Nordic city Regions. Nordic Council of Ministers, 2006.

[26] R. Bennett and S. Savani, "The rebranding of city places: An international comparative investigation," Int. Public Manag. Rev., vol. 4, no. 2, pp. 70-87, 2003.

[27] B. S. Blichfeldt, "Unmanageable place brands?," Place Brand., vol. 1, no. 4, pp. 388-401, 2005.

[28] G. Hankinson, "Location branding: A study of the branding practices of 12 English cities," J. Brand Manag., vol. 9, no. 2, pp. 127-142, 2001, doi: 10.1057/palgrave.bm.2540060.

[29] M. Giovanardi, "A Multi-scalar Approach to Place Branding: The 150th Anniversary of Italian Unification in Turin," Eur. Plan. Stud., vol. 23, no. 3, pp. 597-615, 2015, doi: 10.1080/09654313.2013.879851.

[30] I. Turok, "The distinctive city: Pitfalls in the pursuit of differential advantage," Environ. Plan. A, vol. 41, no. 1, pp. 13-30, 2009, doi: 10.1068/a37379.

[31] A. Lucarelli and P. O. Berg, "City branding: a state-of-the-art review of the research domain," J. place Manag. Dev., vol. 4, no. 1, pp. 9-27, 2011.

[32] J. W. Jun and H. S. Lee, "Cultural differences in brand designs and tagline appeals," Int. Mark. Rev., vol. 24, no. 4, pp. 474-491, 2007, doi: 10.1108/02651330710761035.

[33] G. Hofstede, "Dimensions of national cultures in fifty countries and three regions," Expiscations crosscultural Psychol., pp. 335-355, 1983.

[34] G. Hofstede, "Culture and organizations (intercultural communication and its importance for survival). Software of the mind," J. Hofstede. L, 1991.

[35] E. T. Hall, The hidden dimension, vol. 609. Garden City, NY: Doubleday, 1966.

[36] H. G. Nuraeni and M. Alfan, Studi budaya di Indonesia. Pustaka Setia, 2013.

[37] L. Alo Liliweri, "Makna budaya dalam komunikasi antarbudaya." Lkis Pelangi Aksara, 2003.

[38] T. Poespowardojo and A. Sera, "Filsafat Ilmu Pengetahuan, Hakikat Ilmu Pengetahuan: Kritik terhadap visi Positivisme Logis, serta Implikasinya," Kompas Gramedia. Jakarta, 2014.

[39] G. Hankinson, "The management of destination brands: Five guiding principles based on recent developments in corporate branding theory," J. Brand Manag., vol. 14, no. 3, pp. 240-254, 2007.

[40] K. Mihalis, "Branding the city through culture and entertainment," J. Aesop, vol. 5, pp. 1-7, 2005. 